\title{
太平洋プレートの沈潜に伴う反流について
}

\author{
東海大学海洋学部 広野卓蔵
}

(昭和 53 年 3 月 4 日受理)

\section{A Countercurrent Accompanying the Descending Pacific Lithosphere}

\section{Takuo Hirono}

Faculty of Oceanography, Tokai University

(Received March 4, 1978)

A countercurrent accompanying the descending lithosphere is inferred to exist under Northeastern Honshu from our earthquake activity charts previously published. The countercurrent is a band of thermal convection lying between the coast of the Sea of Japan and the Aseismic Front defined as the western boundary of the seismic region in the district, at the level of $60 \mathrm{~km}$ depth. Heat source for the convection lies on the top edge of the slab just under the Volcanic Front, which is the centerline between the horizontal limits of the convection. The motive power of the convection is magma produced by frictional heating between the upper mantle and the descending slab.

The dimensions of the convection are, in vertical section, $120 \mathrm{~km}$ in depth, $160 \mathrm{~km}$ in width. It approximately satisfys the theoretical demand for the existence of thermal convection, that is, the dimension ratio of 1.2, and Rayleigh number of the order of not less then $10^{3}$. Deviatric stress along the bottom of the convection adjacent to the top edge of the slab is shown theoretically as vertically compressional that is in accordance with Umino-Hasegawa observation.

The upper part of the convection descending eastward forms a slanting layer which hits the flank of the descending slab at the middle depth of the convection, $60 \mathrm{~km}$, and then turns toward the heat sourse. Momentum change brought about by the abrupt directon chang of the current results in a bending moment exerted on the descending slab, which, forming a couple with another one exerted on it at the trench axis, causes a pure bending of the slab between the trench and the middle point of the convecton.

\section{§1. はしがき}

日本列島付近は太平洋プレートの沈み込みの場であり，その付近に拈ける地質学的ならびに 地球物理学的現象は，すべてその沈み込みの運動に依存しているといわれている．しからば当 然，沈み込みに伴う反流があつてしかるべきであるが，従来そのような反流について具体的に 論じた論文は現われていない。ただ，反流の存在が予想される事柄はいろいろと整つていた。 例えば, プレートの沈み込みによる摩擦熱が火山の熱源になつているらしいこと (TURCOTTE and SCHUBERT, 1973), 深さ 60 200 km に低速度層があること (KANAMORI and PRESS, 
1970)，またプレートが島弧の下に沈み込むときに，島弧側も，海溝に間吵ができないように， 沖に向つて動く必要があること (ELSASSER, 1971), 深発地震帯が二層構造であること(海野. 長谷川, 1975) などである.

筆者は先に協力者と共に, 日本附近の地震活動分布図（気象研究所，1972）を作成したが*, それによつて，このよらな反流の存在を確め，さらに反流による応力分布が，浅い層の地震を 起す原動力となつていると思われるので報告したい，まず本報では，主として東北地方につい て，このよらな反流（対流）が存在することを示した。

\section{§ 2. 火山前線を軸とする熱対流帯}

先に湯村・広野・和達（1970）は日本の深さ別の地震活動域を示したが，東北地方の大陸棚 の地震活動域は，西縁が特に明瞭であつたので，それを Seimic Front と呼んだ. 後に吉井 (1975) はそのモ木面直下の位置 $(30 \mathrm{~km})$ を Aseismic Front と命名した。現在この名称が

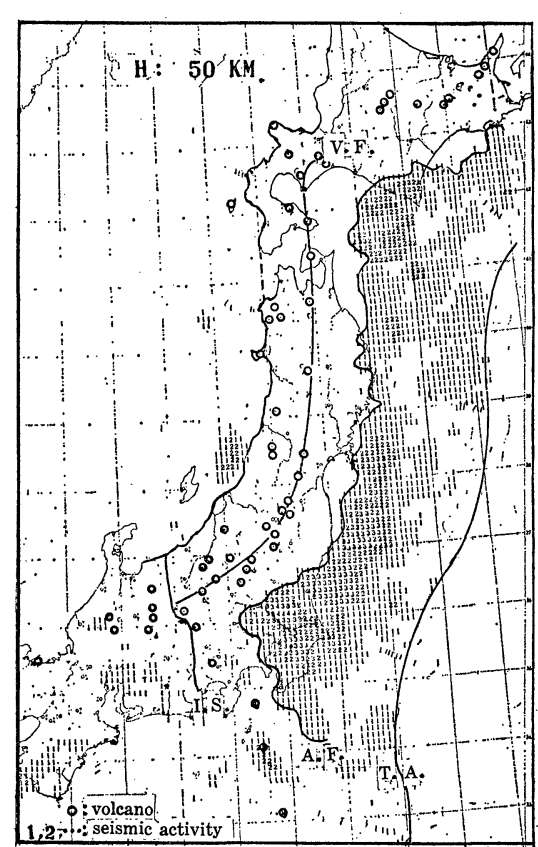

Fig. 1. Seismicity at the depth of $50 \mathrm{~km}$ in Northwestern Honshu, and Aseismic Front (AF) running roughly in parallel with the coast of Japan, the axis of Japan Trench (TA) and Volcanic Front (VF).
一般に広まつているので, ここでもこ れを用い, 簡単に $\mathrm{AF}$ (線) と呼ぶこ とにする。ただしその位置は地震活動 の最も盛んな深さとする.

Fig. 1 は深さ $50 \mathrm{~km}$ の地震活動 分布図を示したものであるが，実際の $\mathrm{AF}$ の深さは東北地方で $50 \sim 60 \mathrm{~km}$ 付近と思われる. 以前にも指摘した通 り [湯村・等 (1970)], 東北地方に和 いては，AF 線と日本海沿岸線が平行 していて, その平均距離は $160 \mathrm{~km}$ で ある. $\mathrm{AF}$ 線と日本海沿岸線の中央を 那須火山帯 (火山前線, 以後 VF と呼 ぶ）が走つている。 また日本海溝の軸 も南北両端付近を除いて AF 飞平行 で，その距離は約 $210 \mathrm{~km}$ である。 ま ず，問題のプレートの反流（対流）は， * 同図の作り方 資料は気象庁発表主要地震 15,664 箅 $(1926-1970)$. 各地震を震央緯度経度 $0.1^{\circ}$, 深 さ $10 \mathrm{~km}$ 間隔の格子に分配する. 1 つの地震の点数 1 亿対し，それに隣接する格子点に $0.14 \sim 0.5$ を分配した後，各点の総計を取る。総計を $1 \sim 5,5<\sim 10,10<\sim 50,50<の 4$ 階級に分け，地震 活動度を各々 $1 ， 2 ， 3 ４$ とし，断面図上の格子点に印字寸る. Fig. 1，2，6，7，10 参照. 
火山前線を軸とし， AF 線と日本海沿 岸線を両水平限界として，その間を南 北に帯状に横たわり, 太平洋プレート を相対的に引き达む方向に循還してい ると考觉る。

海野・長谷川 (1975) は東北日本の 微小地震の研究に扮いて, 緯度 $39^{\circ} \sim$ $40^{\circ} \mathrm{N}$ の断面で, 深さ約 $50 \mathrm{~km}$ より深 部で, 深発地震帯が二層構造を持つこ とを発見した。 この断面に相当する我 々の分布図は Fig. 2 の通りで, 海野, 長谷川に従つて $50 \mathrm{~km}$ 以深に上記二

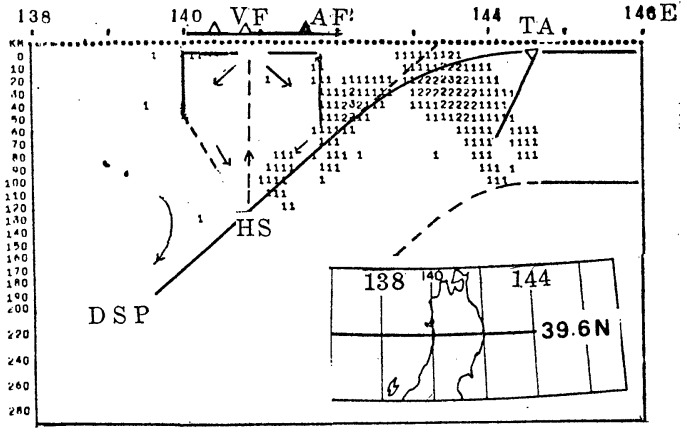

Fig. 2. Seismicity in the vertical section of the latitude $39.6^{\circ} \mathrm{N}$ including aftershocks of the Sanriku Eq. of 1933, and the outline of the thermal convection. The top edge of the descending lithosphere is drawn along the slip surface discovered by UMINo and HASEGAWA for the deeper part than $50 \mathrm{~km}$ in depth.

層構造の滑り面が書き入れてある。また滑り面の上端から海溝までは円弧で結んである（§5参 照)．この一連の線はプレートの上面を表わすものと考える．滑り面の傾斜角は約 $33^{\circ}$ である。 三陸地震 (1933) の震源は丁度この断面図の海溝附近にあり, 図に書き込まれた斜線はその 断層の位置を示す $\left(\mathrm{N} 70^{\circ} \mathrm{W}, \mathrm{D} 50^{\circ}\right.$ ，地震研究所， 1973) 恐らくこの為と思われるが，約 100 $\mathrm{km}$ の下まで，プレートが破壊されていることが分る．これによつてプレートの厚さは約 100 $\mathrm{km}$ と考光られ.

Fig. 2 により，火山前線を含む鉛直面と深発地震滑面との交線の深さは約 $120 \mathrm{~km}$ で，こ の深さは，東北地方の深さ $60 \mathrm{~km}$ 以下に広がる S 波減衰係数大なる層の中心 $100 \mathrm{~km}$ に近い [WADATI， et al. (1969)]. また東北地方に执いては，太平洋側より，AF の深さより深く西 方に下る地震活動域の範囲は, 我々の地震活動分布図によれば，火山前線の手前でほとんど終 つている（微小地震活動を除く），以上より考えれば，太平洋プレートが西方へ沈降するとき， 大陸棚を構成する地殼との間に起す摩擦熱（または歪による内部摩擦熱）により，深さ $50 \sim 60$ $\mathrm{km}$ (AF の深さに一致) でマグマが発生し，自ら作つた滑面に沿つて下方に運ばれ，この深 さまで来て, まわりの地殼がすべて熔融されたところで初めて解放され, 上昇し, 対流の熱源 となると考劣られる．ここが火山前線の直下であり，対流の下の限界である．これより上昇し たマグマの圧力により，脊梁山脈が支えられ，かつ余力は地表付近より東西方向に下降流を生 じると考えられる.

対流がプレートと接している底部では，AF に近いほど内部の地震が活発であるから，その 付近の状態は固体に近く, プレート面に沿つて下つて来るマグマの層を, 熱源の位置まで閉じ 
込めて和くことができる.

上述の如く, 対流圏の底の東側半分は, プレートに接して西に傾斜しているが, 対流の水平 限界は火山前線に対してほぼ対称であるから，底部の西側も東側に対して対称に近い構造を持 つものと考えられる。したがつて太平洋側と同様, 日本海側でも, 海底物質を東方に引き込ん でいるものと思われる。

\section{§3. 対流発生の条件}

対流理論によると, 熱対流が起るためには Rayleigh 数 $R=\alpha \beta g h^{4} / k \nu$ が臨界值のオーダー $10^{3}$ に等しいか，それより大きくならなくてはならない[島津 $(1969), 280$ 頁]. 但し $\alpha$ : 熱膨 脹係数, $k$ : 熱抎散率, $\nu=\mu / \rho$ : 動粘性係数, $g$ : 重力加速度, $h$ : 流体層の厚さ, $\beta:$ 上下方向 の温度勾配である，種々の場合のขのオーダーの変化に対し， $\alpha, \beta, k, g$ のそれはあまり 変らないとして，島津がマントル対流の計算に使用した数值を借用した. 即ち， $\alpha=2 \times 10^{-5 \circ} \mathrm{C}$ $/ \mathrm{cm}, k=10^{-1} \mathrm{~cm}^{2} / \mathrm{sec}, g=10^{3} \mathrm{gal}, \beta=1^{\circ} \mathrm{C} / \mathrm{km}$ [島津 (1969), 281 頁] と $h=120 \mathrm{~km}$ を入れ ると $R=4 \times 10^{22} / \nu$ となる.すなわち， $\mu<10^{19}$ ならば $R>10^{3}$ となる， $\mu$ の值の例としては， スカンジナビヤ半島隆起から求められた $10^{22} P$, また日本の火山熔岩では昭和新山の $>10^{10} P$ が日本での最高值と思われる [島津 (1967), 42 頁]. これらの数值を参考にすれば, 今の場 合, 十分対流存在の可能性があるといえる.

次に，最も起り易い対流の深さと幅の比は理論的に 1.2 である (寸法比の法則)。これは竹 内のテキスト $(1972,286$ 頁) により次の如く求められる. 粘性流体中の熱対流の上下速度成 分を $w_{m, n}$ とすると

$$
\begin{array}{lr}
w_{m, n} \propto \exp \left(i \pi m x / L_{1}\right) \exp \left(i \pi n y / L_{2}\right), & m, n: \text { 整数, } \\
a^{2}=(\pi h)^{2}\left\{\left(m / L_{1}\right)^{2}+\left(n / L_{2}\right)^{2}\right\}, & a \text { : 固有值, }
\end{array}
$$

但し， $L_{1}, L_{2}$ は水平 2 方向 $(x, y)$ の対流の幅， $h$ は深さである (Fig. 3). 自由・固定を

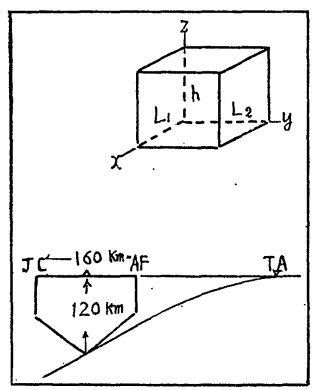

Fig. 3. Dimensions of the convection.
上下の境界条件とすると， $a=2.68$, $R_{c}=1101$ となる. $m=1, n=0$ とす ると， $L_{1} / h=\pi / 2.68 \risingdotseq 1.2$ となる. 今 の場合 $160 \mathrm{~km} / 120 \mathrm{~km} \doteqdot 1.3$ でほぼ 理論值に一致する.

海野・長谷川によれば, 前記 2 層構 造の発震機構は; 主応力が上層では斜 面に沿うて圧力で, 下層では張力であ 
る. 対流理論によれば [竹内 (1972), 285 頁], 対流中の水平面に対する垂直応力 $Z_{z}$ は, $w$ と

$$
\nabla^{2} Z_{z}=\mu\left(\nabla^{2}+2 V_{1}^{2}\right) \frac{\partial w}{\partial z}
$$

の関係がある。但し

$$
\nabla^{2}=\frac{\partial^{2}}{\partial x^{2}}+\frac{\partial^{2}}{\partial y^{2}}+\frac{\partial^{2}}{\partial z^{2}}, \quad \nabla_{1}^{2}=\frac{\partial^{2}}{\partial x^{2}}+\frac{\partial^{2}}{\partial y^{2}}
$$

今,

$$
w_{m, n, s} \propto \exp \left(i \pi m x / L_{1}\right) \exp \left(i \pi n y / L_{2}\right) \exp (i \pi s z / h)
$$

と和くと,

$$
\left(z_{z}\right)_{m, n, s} \propto \frac{\partial w_{m, n, s}}{\partial z}
$$

となる．但し $z$ 軸は上方に取つてあり， $s$ は整数である， $w$ は対流の底と地表で 0 である から，途中極值を一つ持つとすれば $s=1$ が主要成分となり，その位置はほぼ中間 $50 \sim 60 \mathrm{~km}$ の深さとなる．また水平方向の主要なるものは $m=1 ， n=0$ であるから，（1）より，姇流 の降下の部分では，地表から極值の深さまでは $Z_{z}$ は正，それより深くなると負になる (Fig. 4). 海野, 長谷川が発震機構を決めたのは $50 \sim 150 \mathrm{~km}$ の深さであるから，滑面の上層が圧 カであることは理論と一致する.

二層構造の下層の中の発震機構の主応力が上層と異る型を持つ事は, 対流圈とプレートの相 互の結合が密でないことを示すすなおち，両者間の応力の伝達機構が固体のように歪による のではなく，粘性流体のように変形速度によるためと思われる，つまり，二重層の滑面が流動 性あるマグマの層であることと一致する.

プレート内に張力が見られる事の説明は 3 通り考学られる. 第 1 は対流の速度はプレートの 沈み込及速度より相対的に速いと考学られるから，対流がマグマの層を隔ててプレートを引づ る. 第 2 は, プレートの自重による下降力, 第 3 は, この対流より更に下方に掠いてプレート に接触する日本海物質による引づり力 (第 1 の場合と類似の作用) である．海野・長谷川 (1975) によれば，プレート内では深さ $100 \sim 150 \mathrm{~km}$ に和いても，主圧力の型は同じ傾向にあるから， 後の 2 者による寄与も十分に考它られる.

対流の東への水平成分は， $\mathrm{AF}$ 以浅では，地殼物質を海溝方面に押し出し，その力は $\mathrm{AF}$ 以 深に働く逆向きの前記第 1 の力と釣合 つている. このため大陸棚は，上面を 押えて下より引く向きの大いなる剪断 力を対流圈から受けることになり, 一 大地震活動の場となつていると思われ る. 飯島・加賀美（1961）により女川

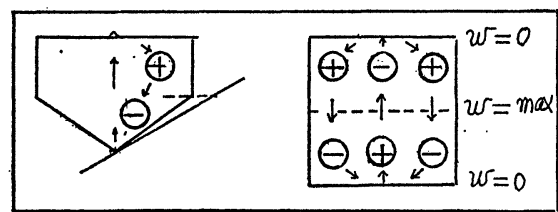

Fig. 4. Schematic distribution of deviatric stress normal to a horizontal plane in a convection current. +: Tension, - : Compression. 
200 浬沖で中新生の風食痕のある磁が採取されたことは，上記の東方向きの力のために，陸の 表層が東方海上に押し出されている証拠と思われる.

\section{§ 4. 海溝-AF の水平距離}

Fig 2 に見られるように，プレートの滑面は AF 以深は全く直線的である.プレートの上 面は東方遙か沖合から海溝まで海底面としてやはり注湆線的である，海溝から AF の間だ

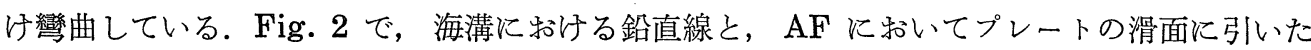
垂線との交点より両者のプレート面までの長さが，注注等しいことを遇然発見した，以後これ らが等しいとして議論を進める.

この関係により, 海溝-AF の水平距離 $l$ は, 滑面の傾斜角 $\theta$, 対流の深さ $h$, 幅 $2 a, \mathrm{AF}$ の深さ $f$ が分れば,

$$
l=(h-f) \cot \theta+f \cot (\theta / 2)-a
$$

より求められる (Fig. 5). $\theta=33^{\circ}, h=120 \mathrm{~km}, a=80 \mathrm{~km}$ とし, $f=50 \mathrm{~km}$ とおくと $l=196$ $\mathrm{km}$ となり， $f=60 \mathrm{~km}$ と打くと $l=215 \mathrm{~km}$ となる．実際は $210 \sim 220 \mathrm{~km}$ である．後者，即 ち $f=h / 2$ が実際と一致することになる，すると， VF-海溝の距離を $L$ とすれば， $L, f$ の 関係は,

$$
L / h=(\cot \theta+\cot (\theta / 2)) / 2,
$$

また， $L / h=r, \cot \theta=e$ と新けば,

$$
r=\left(2 \mathrm{e}+\sqrt{e^{2}+1}\right) / 2, \text { または, } e=\left(4 r-\sqrt{4 r^{2}+3}\right) / 3
$$

となる。ついでながら，海溝での鉛直線の長さ TO $(R)$ と $h$ との比は，次のようになる.

$$
h / R=2(1-\cos \theta) \text {. }
$$

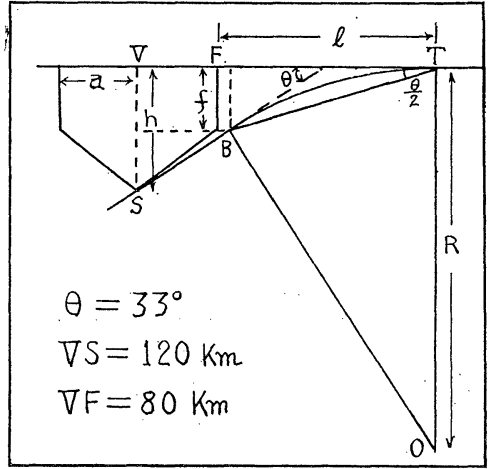

Fig. 5. Geometry for calculating the horizontal distance of $\mathrm{AF}$ from the trench axis, (FT), radii of the curvature of the slab at the trench $(\mathrm{T})$ and at the depth of AF (B) being put equal.

\section{§5. プレートに働くカ}

プレートの湾曲を薄板の弾性変形と して説明することを考える．上記の如 く湾曲部の両端に括ける法線の長さが 等しくなるので，湾曲部の外側の延長 線が共に直線をなすことも考慮に入れ ると，湾曲部の両端に和ける応力は， 両法線のなす角の二等分線に対して対 称になつていると考觉られる。 
CALDWELl et al. (1976) および PARSONS と MOLNAR（1976) は，プレートが外洋から海 溝に沈み込む前に，その上面が基準面から盛り上つている現象を，海溝に执いて，弾性薄板と 考えたプレートの切口に作用する応力によるものと考え，その応力の強さを計算した，その結 果, 水平力の有無にあまり関係なく, 専ら曲げモーメントのみで, 海底隆起の形態が説明され ることを示した。 即ち, 海底の盛上り部分の下方に働く重力が，曲りによるはね上り力を押兄 て釣合つている，彼等の扱つたのはマリヤナ，小笠原，千島，アリウシヤン等の海溝で，我々 のとちがつて地震活動の少ない場であるが，水平力はいざ知らず，今の場合でも，プレートの 曲りに関する限り, 海溝付近では, 曲げモーメントのみが働いていると考えることができる. したがつて，それと対称的な位置にある AF 以深の部分についても，AF の位置のみに海溝 のものと同じ強さの曲げモーメントが働いていて, AF より以深では, プレートが隔てる上下 物質の密度差その他によつて，AF 点に働く曲げモーメントによるはね上り力が押えられてい ると考えることができる.

プレート内に起る曲げモーメントは, 板の面に直角な断面に作用する下向きの剪断応力に比 例する，またかような剪断応力は，プレートに接する対流の圧力の垂直変化によつて生ずると 考えられる，プレートに及ぼす対流の圧力 $p$ (静水圧よりの偏差) は，竹内（1972，285 頁) より, $w$ と次の関係がある.

$$
\nabla_{1}^{2} p=-\mu \nabla^{2} \frac{\partial w}{\partial z}
$$

したがつて, 対流の主要成分について $p \propto-\frac{\partial w}{\partial z}$, これり, 深さによる圧力変化は $|w|$ に 比例し，その極值は $w$ の極值，すなわち $\mathrm{AF}$ の深さで起ることが分る．また $\mathrm{AF}$ 以深では 曲げモーメントによるはね上りを押える力ともなる. 次に実際の例を見る.

Fig. 6 は仙台の北を通る緯度 $38.6^{\circ} \mathrm{N}$ の断面の地震活動分布図であ る. 図は新潟地震 (1964) と宮城県北 部地震 (1962) の余震域を通つている. 火山前線より東側の地震ブロックは後 の地震によるもので, 板状に東下りに $\mathrm{AF}$ に向つて傾斜しているのが見られ る. その先は消杂ている. しかし，そ の傾斜方向には，プレートの中までそ の力の影響が見られるので，その動き は $\mathrm{AF}$ にまで到達しているものと思

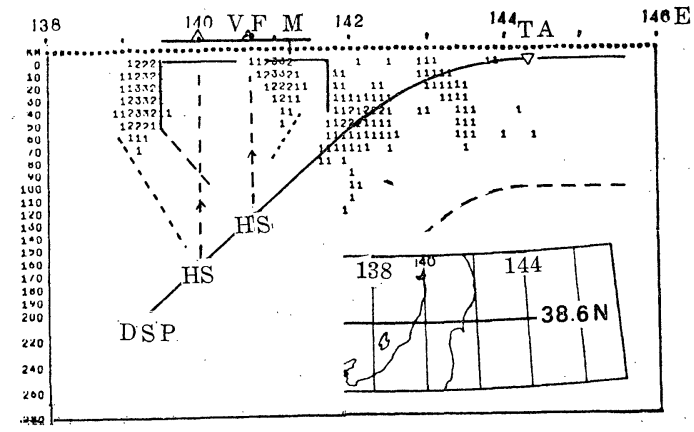

Fig. 6. Seismicity in the vertical section of the latitude $38.6^{\circ} \mathrm{N}$ including aftershocks of both the Niigata Eq. of 1964 (Left) and the Northern Part of Miyagi Pref. Eq. of 1962 (Center), and double cell of convections. 


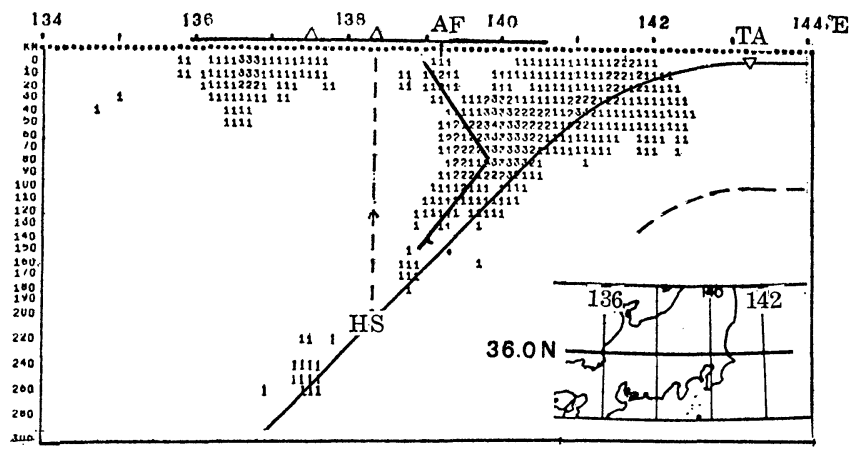

Fig. 7. Another example of a thermal convection at the vertical section of the latituds $36.0^{\circ}$ $\mathrm{N}$. The descending convection currenct and a part of the top edge of the lithosphere deeper than $100 \mathrm{~km}$ in depth are drawn after Tsumura (See Fig. 8).

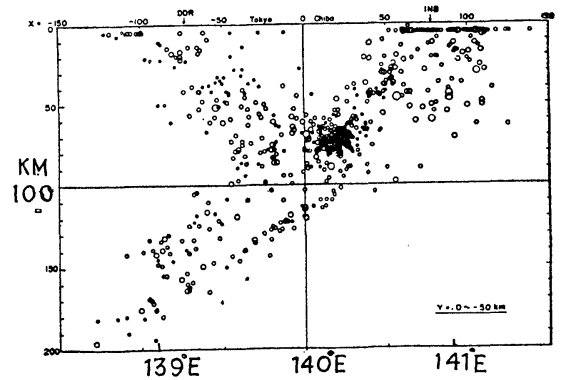

Fig. 8. Vertical distribution of hypocenters of microearthquakes for the area south of the latitude $36^{\circ} \mathrm{N}$ with $50 \mathrm{~km}$ width [Tsumura (1973)]. Twofold structure along the eastern boundary of the convection can be seen.
われ，その後は，熱源に向つて急角度 で方向転換しているものと推擦される. その際の運動量変化がプレートに強大 な曲げモーメントを与える力になつて いると考觉られる．ブロックの傾斜角 は約 $40^{\circ}$ である. 本震の深さは $0 \mathrm{~km}$, 発震機構による断層面の向きと傾斜 角は $\mathrm{N} 75^{\circ} \mathrm{E}, 59^{\circ}$ で逆断層であつた (ICHIKAWA, 1971).これらのことは上 の考光と矛盾しない。上の例で推擦し

た部分の様子は，次の例でより明瞭に見ることができる。

Fig. 7 は東京の北を通る緯度 $36^{\circ} \mathrm{N}$ の鉛直断面の地震活動分布図である. これは上に述べ た東北地方の熱対流帯の南続きで，関東地方から中部地方にかけて広がる本邦最大の熱対流渦 と考えられるものである．図中のプレート上面および対流の境は，津村 (1973) が作つたほぼ 同じ緯度帯の中の微小地震活動の鉛直分布図（Fig. 8）によつて引いたものである.

この対流の中心は八ケ岳付近, 深さ約 $190 \mathrm{~km}$, 対流の幅約 $240 \mathrm{~km}$, 傾斜角約 $33^{\circ}, \mathrm{AF}$ に 相等する深さは約 $100 \mathrm{~km}$ で茨城県南西部の下あたり，渦の 縦横の寸法比は東北の場合と同 じである．Fig．８を見ると，対流の動きを示していると思われる微小地震の列が西上から東 下に傾斜し，約 $100 \mathrm{~km}$ の深さで約 $80^{\circ}$ の角度で不連続的に方向転換していることが 2 重層 の曲り方で明瞭である. 注目されるのは, 対流圈がプレートばかりでなく, 周囲の上部マント ルとの境界面でも滑面を作つていることで，このため方向変換点付近では三重層となつている ように見える。 
以上の例に見られるように対流の動 きは直線的で, かつ $\mathrm{AF}$ に作用する曲 げモーメントは集中的である。かくし て, プレートの海溝から AF に到る湾 曲部は, 両端に作用する曲げモーメン トによる単純曲りと考学られるから， その形は円弧を以て表わすことができ る (Fig. 2, 5 参照). プレートの湾曲部に働く摩擦力や, プレートが隔てる上下の物質の密度の相異による浮力の違いなどが，曲げモーメントに不対称 の影響を及ぼすと考兄られるが，前記 2 法線の等長の事実によつて，それらは殆んど無視され 得る程度のものと思われる。

§2で, 太平洋プレートの厚さを $100 \mathrm{~km}$ 程度と考えたが，湾曲に耐える厚さは更に薄いも のと思われる. CALDWELL 等の場合はいずれも約 $30 \mathrm{~km}$ と求められて拈り, 今の場合も同程 度のものと思われる．プレートの湾曲部の曲率半径は東北地方の場合 $372 \mathrm{~km}$ であるから, 厚 さ $30 \mathrm{~km}$ 程度であれば十分薄板と考えることができる. 残りの厚さは降伏しながら弾性層と 共に沈んで行くものと考えられる. Fig. 9 に, 今までの知識で画いた熱対流の概略を示す.

\section{§ 6. 鳥海火山帯の役割}

Fig. 6 に現われた新潟地震の余震ブロックは, 日本海側にある鳥海火山帯を中心とする熱 対流によるもののように見える. その下のプレート面までの梁さは $160 \mathrm{~km}$ で，その幅は約 $200 \mathrm{~km}$ である. この対流の熱源は, 東側の太平洋プレートの沈み込みに対応して, 日本海側 の物質が沈み込む際の摩擦熱が集積したものと考えられる．鳥海火山帯の産出する岩石の本源 マグマは, VF に属する火山とやや異るハイアルミナ玄武岩であることも (KUNO, 1960), こ の考觉を裏付ける.

もし，日本海物質をプレートまで引き达む力が，VFによる熱対流のみに原因するものであ るならば，鳥海火山帯とVF とは平行になると思われるが，実際はそらでなく，これと斜に交 わつている，これは，日本海物質自身にも独自の動きがあることを示すものと考劣られる.

鳥海火山帯の火山活動はVF の活動よりかなり弱く, 火山数にして 3 分の 1 弱である（杉村 1965). したがつて，VFによる対流と同様，独自の対流圈を形成するが，VFよりも勢の弱い ものと思われる．総じて，地下の物質の運動は極めて遅いから，各自の応力分布は釣合の状態 


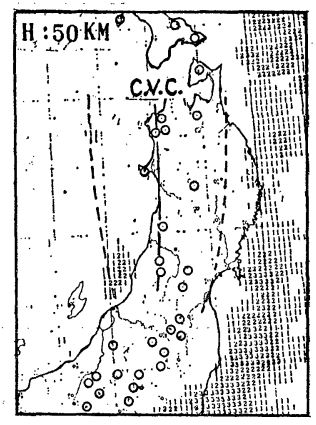

Fig. 10. The east and west limits of the thermal convection band due to the Chokai Volcanic Chain taking the dimension ratio, 1.2 , to the depth of the slab edge under the volcanoes.
にあり，したがつて両者が共存すると きには簡単な重ね合せによつて合成さ れる(重祆合せの原理)。但し，この ときの応力は静水圧を除いたものであ る. これら 2 つ対流の重ね合せで最 も剪断応力のかかるのは, 恐らく重ね 合せから互にはみ出した部分であらう。 なぜなら，その部分は，対流速度の異 る両境界面に境されるからである。气 のため, ここが地震の起り易い層とな つていると思われる．Fig. 6 でこの部分が東では宮城県北部地震の震源域となり，西では新 潟地震の震源域となつている.

鳥海火山帯を軸とし，プレートまでの深さの 1,2 倍の幅を東西側に引けば Fig. 10 のよう になり，その東側は，いわゆる盛岡・白川線にほぼ一致し，西側は，日本海沖に起る地震ブロ ックの位置に一致する．新潟地震の震源の深さは $40 \mathrm{~km}$, 発震機構による断層面の方向と傾斜 角は $\mathrm{N} 70^{\circ} \mathrm{W}, 70^{\circ}$ で，対流の上半分が西に傾斜することと矛盾しない。

\section{§ 7. 結 論}

太平洋プレートの沈み込みに伴つて，東北地方の下に，火山前線を軸とし，日本 海沿岸と Aseismic Front との間に，帯状の熱対流が生じている，対流の熱源は，火山前線の直下のプ レート面上に位置し，プレートの沈み込みに伴ら摩擦熱の集積したものと考兄られる．対流の 東方への下降部分は板状をなし，深さ半ばでプレートに出合う，そこから一転してプレートに 沿い熱源に戻る，方向転換の際の運動量変化が，プレートを水平から沈み込みの方向へ変える 曲げモーメントの原因となる。これで，海溝から AF までのプレートの形は円弧となる，対流 の東向き水平方向の圧力が，上半と下半で逆になり，このため $\mathrm{AF}$ と海溝との間に剪断応力の 場（地震の場）を作る.

VF を軸とする対流圈に比し弱勢力であるが，鳥海火山帯を軸とする対流圈がある. 太平洋 側と同様，日本海物質の引き込みによる摩擦熱の集積がその熱源となつていると思われる．こ の対流圈が，日本海沖の地震活動の原因になつている．また，両対流圈の重なり合いによつて 内陸の地震帯が形成されている。 
謝辞

竹内均東京大学教授には, 同教授の著書につき, また東北大学の海野徳仁氏には, 同氏と長 谷川昭氏の論文につき，それぞれ御丁寧な御教示をいただいた。ここに厚く感謝の意を表する。

\section{文献}

Caldwell, J.G., W.F. Haxby, D. E. Karig and P.L. Turcotte, 1976, On the Applicability of a Universal Elastic Trench Profile, Earth and Planetary Sci. Let., 31, 239-246.

ELSASSER, W.M., 1971, Sea-floor Spreading as Thermal Convection, J. Geophys. Res., 76, 11011112.

飯島 東・加貿美英雄，1961，三陸沖一釧路沖大陸斜面の新第三紀以降の構造発達史，地質雑，67，561577

IcHIKAWA, M., 1971, Reanalyses of Mechanism of Earthquakes which occurred in and near Japan, and Statistical Studies on the Nodal Plane Solutions Obtained, 1926-1968, Geophy. Mag., 35. 207-274.

地震研究所, 1973, 四説日本の地震.

KanamoRI, H. and F. Press, 1970, How thick is the lithosphere?, Naturs, 266, 330.

気象研究所地震研究部, 1972, 日本付近の研究活動分布図, 気象庁技術報告, 81, 1-112.

Kuno, H., 1960, High-alumina Basalt, Jour. Petrology, 1, 121-145.

Parsons, B. and P. Molnar, 1976, The Origin of Outer Topographic Rises associated with Trenches, Geophys. J. R. Astr. Soc., 45, 707-712.

島津康男, 1967, 地球の進化, 岩波書店.

島津康男, 1969, 地球内部物理学, 裳華房.

杉村 新, 1965, 火山の分布とマントルの地震との関係, 火山, 10, 37-58.

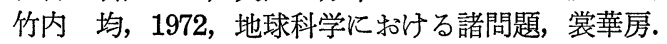

津村建四朗, 1973, 関東地方の微小地震活動, 関東大地震 50 周年論文集, 地震研究所, 67-87.

Turcotte, D.L. and G. Schubert, 1973, Frictional Heating of the Descending Lithosphere, J. Geophys. Res., 78, 5876-5886.

海野徳仁・長谷川昭，1975，東北日本にみられる深発地震面の二層構造について，地震， $228 ， 125-139$.

Wadati, K., T. Hirono and T. Yumura, 1969, On the Attenuation of S-waves and the Structure of the Upper Mantle in the Region of Japanese Islands, Papers in Met. Ceophys., 20, 49-78.

吉井敏起, 1975, “Aseismic Front” の提案, 地震, 2 28, 365-367.

湯村哲男・広野卓蔵・和達清夫, 1970 , 日本付近における地震帯の構造について, 地震, 2 23, 99-121. 